地すべり 第 28 巻 第 3 号

Journal of Japan Landslide Society 28-3(1991)

\title{
地すべり地における間隙水圧変動の観測
}

\section{Pore-water pressure fluctuations in some landslide areas}

\author{
檜 垣 大 助* 丸 山 清 輝* \\ Daisuke HIGAKI Kiyoteru MARUYAMA \\ 吉 田 克 美* 吉 松 弘 行* \\ Katsumi Yoshida \\ Hiroyuki Yoshimatsu
}

\begin{abstract}
Pore water pressure fluctuations are observed in two landslide areas of pre-Tertiary or Paleogene rocks and one landslide area of Neogene rocks.

When the pore water pressure of various depth increases rapidly at the time of heavy rainfall, the landslide movement becomes active in the former two landslides. The pore water pressure fluctuation in the latter one has no relation to the landslide movement, because the measurement of pore water pressure is carried out in impermeable layers where the pore water pressure is not thought to fluctuate frequently. Pore water pressure fluctuation is proved to be an important cause of landslide movement.

The hydraulic water levels of various depth are often measured to be different. According to the groundwater prospecting test or the groundwater level measurement during a period of borehole excavation, impermeable layers make the hydraulic water levels of various depth different to each other. In case that impermeable layers exist in a landslide mass, based on hydro-geological surveys, pore water pressure on the slip surface should be measured for monitoring a landslide slope or designing prevention works.
\end{abstract}

キーワード: 地すべり, 間隙水圧, 地下水位, 水文地質構造

\section{1.まえがき}

地下水の供給は地すべり発生の重要な誘因となる。す なわち，地下水供給による間隙水圧の上昇がすべり面に おけるせん断抵抗力の減少をもたらし, 斜面が不安定化 すると考えられている。このため, 降雨や融雪による地 すべり発生機構の解明や, 地すべり斜面の安定度評価に は,すべり面での間隙水圧の把握が必要である。

一般に, 地すべり地では, 間隙水圧測定の代わりに全 区間に小孔をあけたケーシングパイプ中で地下水位を観 測し，それを静水圧換算して間隙水圧に代用することが 多い。しかし，新第三紀層地すべりでの間隙水圧観測例 では, 地すべり地の地下水は静水圧分布しないことがあ り, また降雨や融雪によって間隙水圧が上昇するものの, その反応のしかたは地すべり斜面の頭部と末端部で異 なっていることが指摘1),2),3) されている。このように地す ベり土塊中の地下水分布は単純ではないにもかかわらず, 間隙水圧の測定例は少ない。

そこで, 地すべり地の地下水挙動の把握を目的として,

* 建設省土木研究所
幾つかの地すべり地において間吵水圧変動の実態を調べ, それと地すべり移動との関係, 及び水文地質構造との関 係について検討した。

\section{2. 対象とした地すべりおよび間隙水圧計設置 の概要}

今回間隙水圧測定の対象とした地すべり地は高知県谷 の内, 静岡県口坂本, 新潟県赤崎の 3 箇所である。

谷の内地区 (図-1) では, 地すべり地形を呈する範囲 は延長 $1,100 \mathrm{~m}$, 幅 $1,000 \mathrm{~m}$ におよぶが, 現在地すべり 移動が顕在化しているのは末端部の斜面で, ここに間隙 水圧計を設置した。地すべり地の地質は秩父帯古生層の 破砕, 風化の進んだ粘板岩, チャート, 輝緑凝灰岩等か らなり, 孔内傾斜計の観測結果によるとすべり面は粘土 化の進んだ輝緑凝灰岩層中にある。

間隙水圧計は調査ボーリング孔 $(\mathrm{BV}-63-2)$ 中に多 段に設置され, その位置はすべり面直上のチャートと輝 緑凝灰岩境界付近 (深度 $63.8 \mathrm{~m}$ ), 粘板岩中の深度 52.8 $\mathrm{m}, 48.3 \mathrm{~m}, 46.4 \mathrm{~m}, 42.3 \mathrm{~m}$ の 5 箇所である。各深度ご との間隙水圧を計るため, 間隙水圧計を所定の深度に入 れ, 間隙水圧計設置部分を中心に $1.0 \mathrm{~m}$ の区間には透水 材として砂を, それ以外の部分には遮水材としてベント 

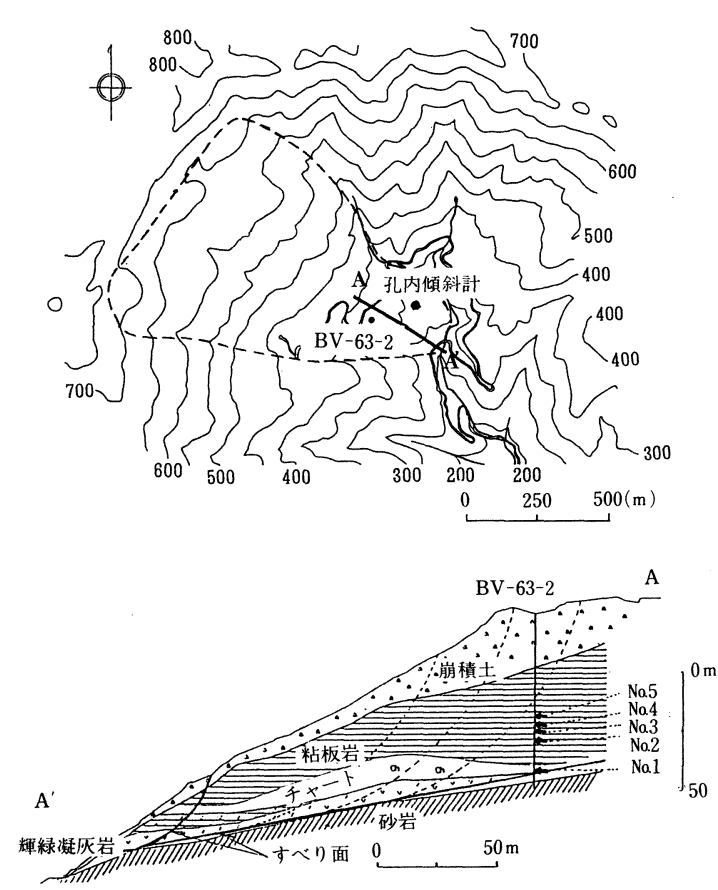

図-1 谷の内地すべりの地形 (上) 及び $\mathrm{A}-\mathrm{A}$ 線の地質断面 図（下）

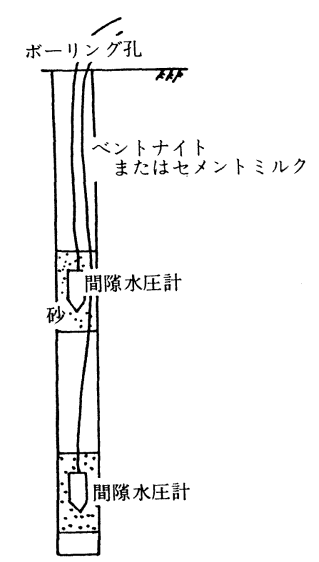

图－２間隙水圧計設置方法

ナイト，セメントミルクを用いた（図一2）。

口坂本地すべり地 (図一-3) は面積約 $2 \mathrm{~km}^{2}$ を超える大 規模な地すべり地で，かつては年間 $1 \mathrm{~m}$ に及ぶ活発な移 動を示していた() が地下水排徐工の施工によって安定化 しつつある。地すべり地の地質は中生代一古第三紀の著 しく破砕された頁岩からなる。間隙水圧計は地すべりブ ロックの中央部 $(\mathrm{BV}-22$ 孔) に設置され, その設置方法 は谷の内地すべりと同様である。間隙水圧観測孔付近の すべり面深度は, 隣接孔での孔内傾斜計観測によって深 さ $53 \mathrm{~m}$ に確認されている5 生じたため, 間隙水圧計は移動土塊中の3筒所（深度 43
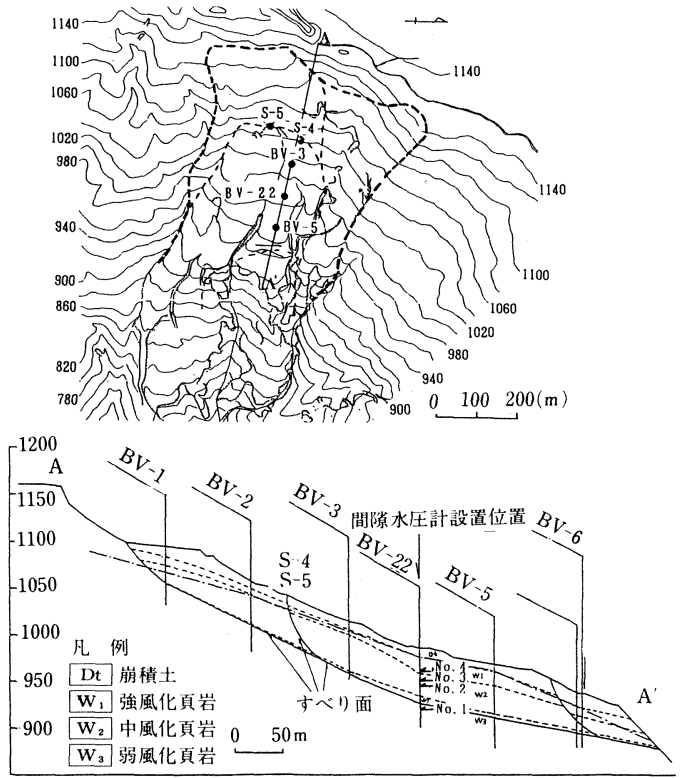

図ー3 口坂本地すべりの地形 (上) 及び A-A'線の地質断面 図

$\mathrm{m}, 36 \mathrm{~m}, 27 \mathrm{~m}$ ）と不動岩盤に 1 箇所（深度 $65 \mathrm{~m}$ ）設置 された。

赤崎地すべり地は斜面長 $1,000 \mathrm{~m}$, 幅最大 $500 \mathrm{~m}$ の規 模で，上部，下部ブロックに分けられる（図-4）。地質 は新第三紀のアルコーズ砂岩, 凝灰岩からなり, 上部ブ ロックには背後にある流紋岩からなる赤崎山よりの岩屑 が堆積している。すべり面は上部ブロックでは崩積土の 下限, 下部では砂岩, 凝扊岩中に推定されている。間隙 水圧計は, 上部ブロックの BV-59-A 孔の深度 $18 \mathrm{~m}$ （すべり面付近）（間隙水圧計 No.1），下部ブロックの $\mathrm{BV}-59-\mathrm{B}$ 孔で深度 $23 \mathrm{~m}$ （すべり面付近）（間隙水圧計 No.1）と深度 $12 \mathrm{~m}$ （間隙水圧計 No.2）に設置された (図一)。設置方法は他地区と同様である。

\section{3 . 間隙水圧測定結果}

\section{1 谷の内地すべり}

図一 5 に谷の内における 1989 年の日降水量, 間隙水圧 変動, 間陌水圧観測孔と隣あわせの孔における従来の観 測方法による地下水位変動を示す。なお，地下水位観測 結果と比較するため間隙水圧については, 各観測深度ご とに水頭の示す水位に変換してある（全水頭に相当し， ここでは換算水位と呼ぶ）。観測間隔は間隙水圧が 24 時 間毎，地下水位は約 7-10 日毎である。

どの深度にも，雨期に間隙水圧が上昇する季節的変動 と降雨に反応する水圧の上昇という共通した変動パター ンが認められる。全期間の観測データの無いNo.5を除 き, 期間中の間陌水圧（換算水位）の変動幅はNo.1，2, 

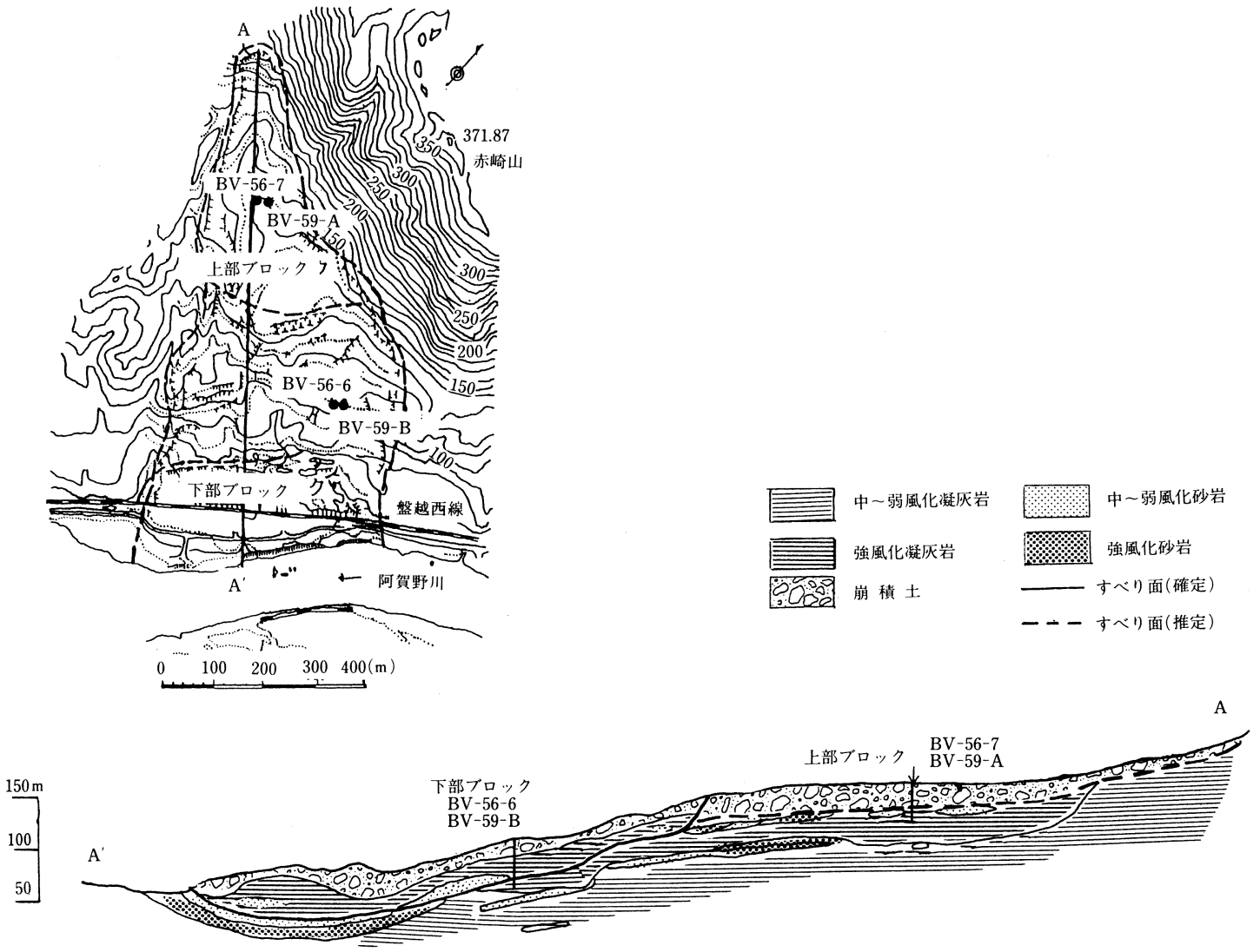

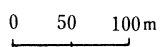

図一４赤碕地すべりの地形（上）及び $\mathrm{A}-\mathrm{A}^{\prime}$ 線の地質断面図

(BV-56-6，59-B は AA'測線から離れており，すべり面位置（深度 $23 \mathrm{~m}$ ）は図と異なる。地質構造は図－11 参照）
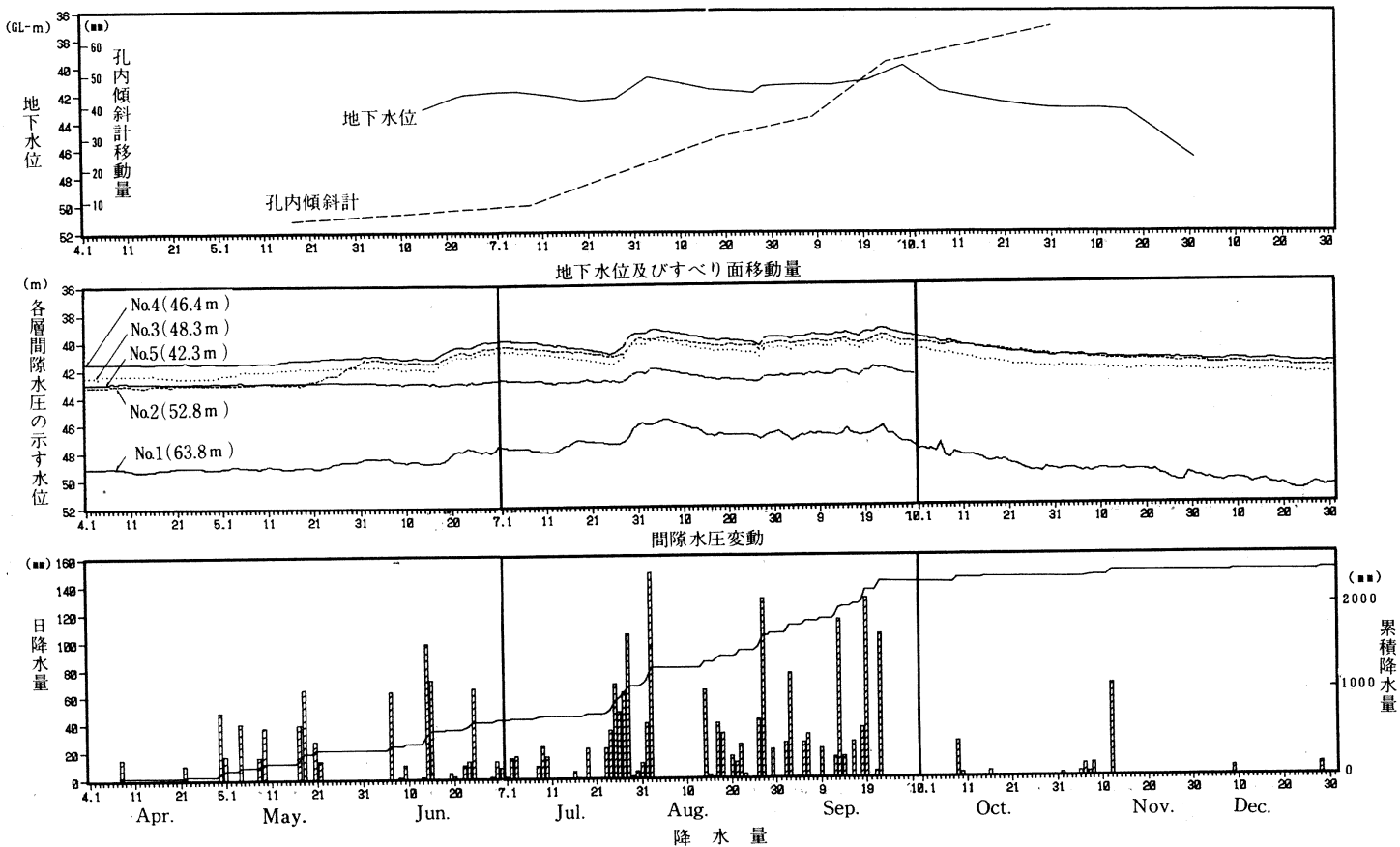

図-5 谷の内における降水量, 地下水位, 間隙水圧変動及び地すべり移動量（1989 年） 


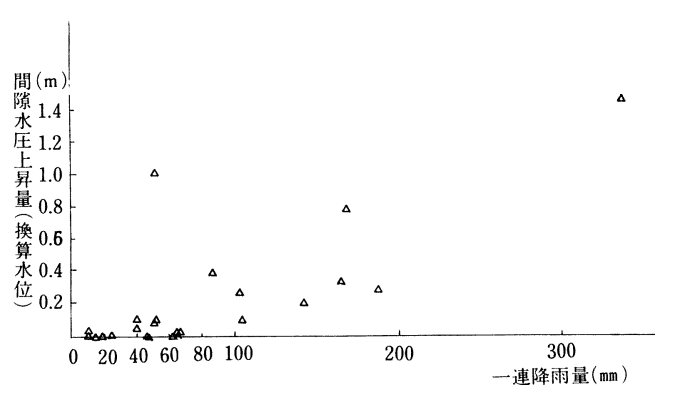

a 谷の内における一連降水量と間隙水圧上昇量（No.4 間隙水圧計）

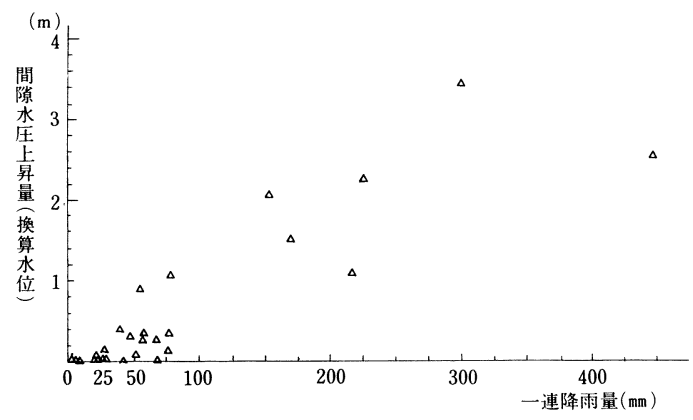

b 口坂本における一連降雨量とそれによる間隙水圧上昇量（間隙水圧計 No.2）

图一 6 一連降水量と間隙水圧上昇量
3,4 の順にそれぞれ $5.4,3.5,2.8,2.7 \mathrm{~m}$ となってお り,すべり面直上にある No.1 が他に比べ大きい。日降水 量と間隙水圧ピーク出現日の比較から, No.2, 3, 4 間隙 水圧計における水圧の上昇は降雨に対し $0-5$ 日, No.1 では 1-6日程度の遅れが見られる。

間隙水圧の上昇はすべての降雨に対し生じているわけ ではない。No.2，3，4間隙水圧計では，降雨に対する水 圧上昇の遅れがいずれも最大 5 日程度であることから， No.4 間隙水圧計を例にとって，一連の降雨(間に 1 日以 上の無降雨日を含まない）開始日の間隙水圧と降雨終了 日から 5 日後までの間隙水圧最大值の差を一連降雨に対 する上昇量として，降雨と間隙水圧上昇量を調べてみた (図一6(a))。この結果，間隙水圧はおよそ $30 \mathrm{~mm}$ 以上の 一連降雨で上昇している。

地下水位と間隙水圧は似たような変動パターンをしめ すが，水位は地表下 40.5-47 m に観測されており No. 2-5 の間隙水圧計の示す換算水位に近く, No.1のそれ とは $5 \mathrm{~m}$ 程度異なっている。

\section{2 口坂本地すべり}

口坂本地すべりにおける間隙水圧変動（6 時間毎観測 で図ー4と同じ表示方法）を図ー7に示す。ここでは季節
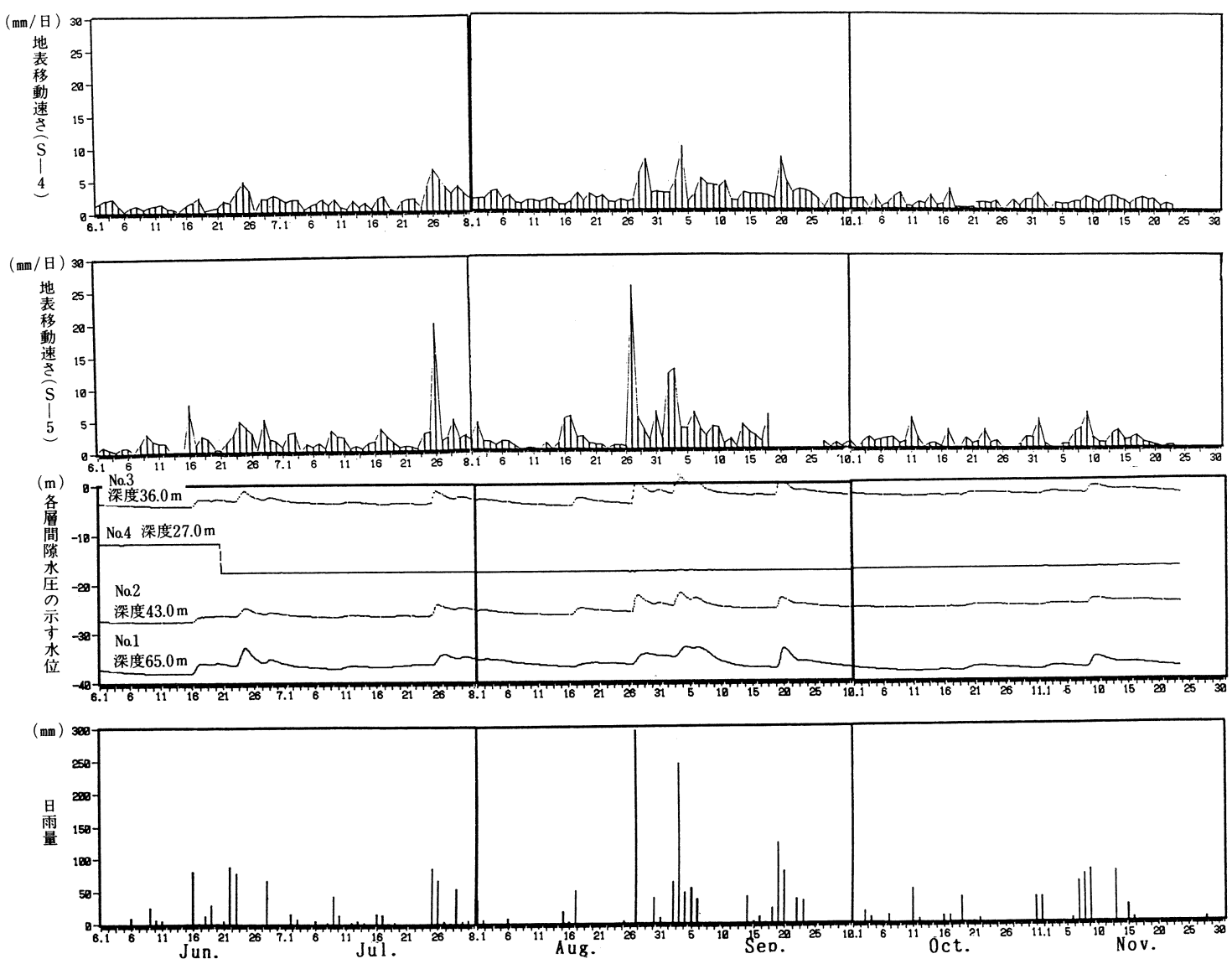

図ー 7 口坂本における降雨量と間隙水圧, 地表移動速さ（1989 年） 
変動は認められないが，地すべり移動層，不動層に関係 なく,どの深度でも間隙水圧が降雨に 0-2 日以内で反応 し急激に上昇している。間隙水圧の変動幅はどの深度で もほほ同じ（約 $5.5 \mathrm{~m}$ ）である。ただし，No.4（深度 27 m) ではある時期から突然全く変動がなくなり不良デー 夕とみられる。

ここでも降雨に対するピーク出現の遅れを考慮し, No.2 の間隙水圧計について,一連降雨の終了日から 2 日 後までの間隙水圧最大值と降雨開始日の最小值の差を間 隙水圧上昇量として，それと一連降雨量の関係を見た (図一6(b))。口坂本地すべりでも降雨量 $30 \mathrm{~mm}$ 程度以上 で間隙水圧が上昇する。

各深度の水圧からの換算水位はすべて異なっており, 最上位と最下位の換算水位は $30 \mathrm{~m}$ も異なる。このこと から, 地下水は静水圧分布していないことがわかる。

\section{3 赤崎地すべり}

赤崎地すべりでは BV-59-A, BV-59-B 孔にそれ ぞれ隣接する BV-56-7, BV-56-6 孔で従来の方法 による地下水位も観測されている。ここでは, 平面的位 置による間隙水圧変化の違いが明瞭である（図一8）。上 部ブロックにある BV-59-A 孔の No.1 間隙水圧計 (深度 $18 \mathrm{~m}$ )による観測では, 間隙水圧は降雨に敏感に反 応し, BV-56-7孔の水位も間隙水圧とほとんど同じ值
で変動している。一方, 下部ブロックの BV-59-B 孔の No.1 (深度 $23 \mathrm{~m}$ ), No.2（深度 $12 \mathrm{~m}$ ) では間隙水圧はあ る程度まとまった降雨がないと変化せず, 応答のしかた もきわめて緩やかであるのに対し, BV-56-6 孔の水位 は降雨時や融雪期に小刻みに上昇していて, 隣接孔の間 隙水圧と地下水位の変動パターンは大きく異なっている。 また, BV-59-B 孔の No.1 と No.2 間隙水圧計の換算 水位は, 前者が後者に比べ $6-8 \mathrm{~m}$ 低い。
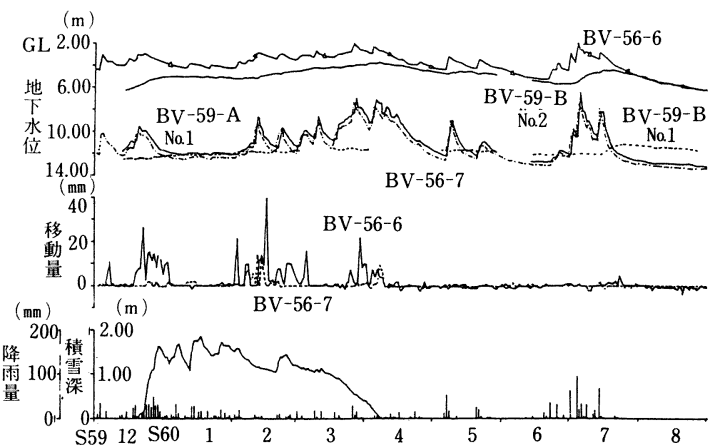

図一8 赤碕地すべりにおける降雨, 積雪, 地下水位 $(\mathrm{BV}-$ $56-6, \mathrm{BV}-56-7)$, 間陌水圧（換算水位で示す） (BV-59-A: No.1 (深度 $18 \mathrm{~m}$ ), BV-59-B: No. 1 (深度 $23 \mathrm{~m})$, No.2 (深度 $12 \mathrm{~m})$ ), 及び BV-566,7 孔における地すべり移動速さ $(\mathrm{mm} /$ 日) の関係

掘進中水位変動

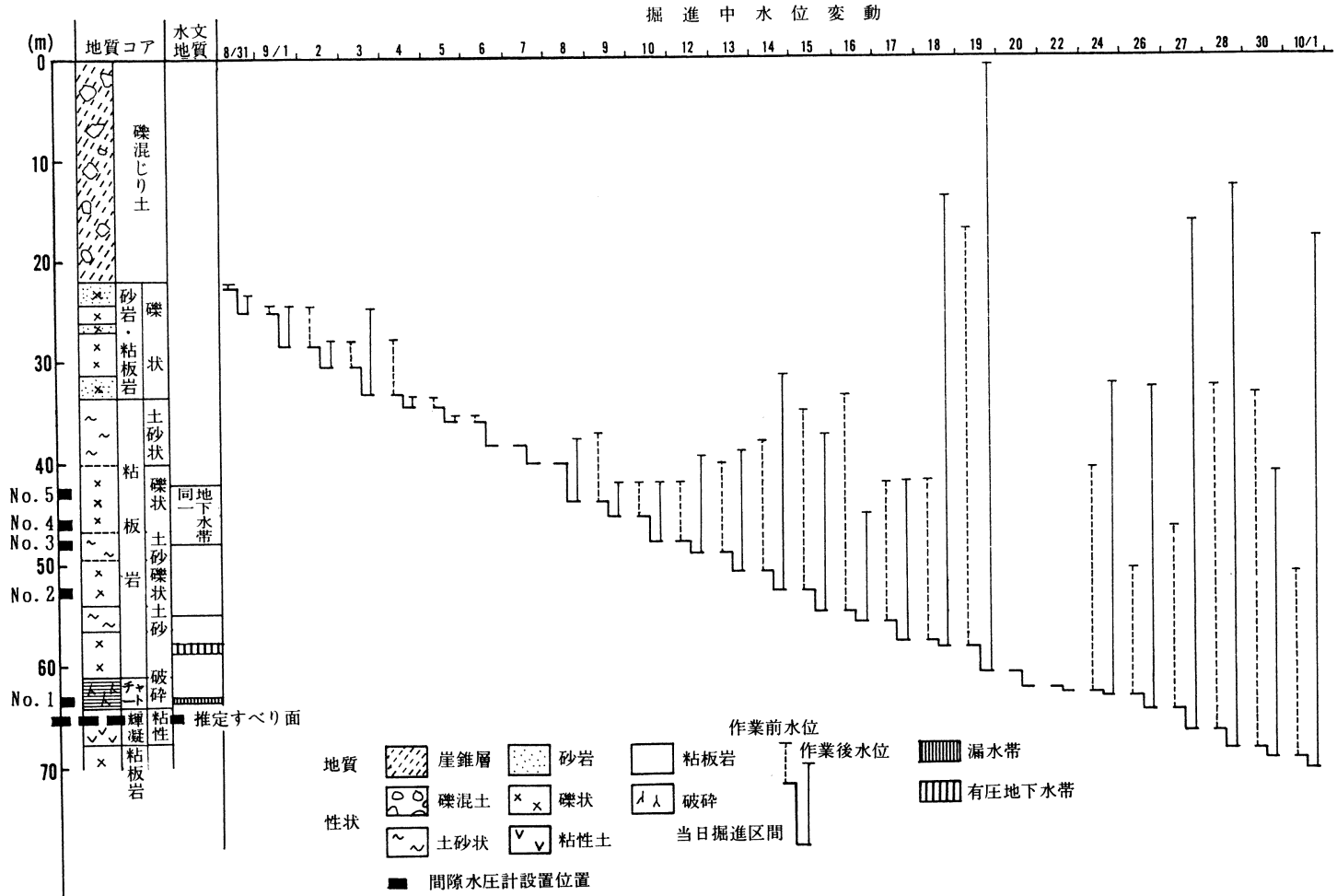

図ー9 谷の内の間隙水圧観測孔におけるボーリング掘進時の孔内水位変動 


\section{4 . 地すべり地の水文地質構造と間隙水圧の関係}

谷の内, 口坂本地すべり地における観測結果からは, どの深度でもおよそ $30 \mathrm{~mm}$ 以上の降雨があると $0-6$ 日以内に反応する間隙水圧の上昇が共通して見られるの に，各深度の水圧からの換算水位は必ずしも同じ值を示 さず，地下水は静水圧分布していないことがわかった。 赤崎地すべりでは降雨, 融雪に対する間隙水圧の応答の しかたが場所により異なり, 地下水位と水圧も変動のし かたが場所により同じ場合とまったく異なる場合があっ た。そこで, 地すべり地の水文地質構造が各層の間吵水 圧変動にどう影響しているかを調べてみた。

調査ボーリング孔掘削中の, 日々の掘進作業前と作業 終了後の孔内水位計測は漏水帯や被圧地下水帯を探るの に役立つ6)。図-9 に谷の内地すべり地の間隙水圧計設置 孔掘削時に観測された水位変化を示す。深度 $44-48 \mathrm{~m}$ の間はずっと $42 \mathrm{~m}$ 付近で一定の水位を示し同じ地下水 帯にあると推定され，この区間にあるNo.3-5 の水圧計 も，おおむね同様の換算水位を示している。一方，深度 63-65 m の区間は作業終了後から翌朝までに大幅な水 位低下の生じた区間に当り，孔内水位はそれまでで最も 低くなっている。したがってこの区間には漏水帯がある と考えられる。深度 $63.8 \mathrm{~m}$ 付近で他に較べかなり低い 換算水位を記録したのは，漏水帯で水圧観測が行われた ためと考えられる。この漏水帯はすべり面のやや上に位
置しており，すべり面直上にしばしば存在するせん断亀 裂帯に沿った漏水面 ${ }^{6}$ であるかもしれない。

口坂本地すべりでは, 間隙水圧観測孔から斜面上, 下 方に $80 \mathrm{~m}$ 程離れたボーリング孔（BV-3，5）で地下水 検層により地下水流動層が調べられている（図一10）。

その結果, $\mathrm{BV}-5$ 孔では電解質投入 60 分後まで深度 $36 \mathrm{~m}$ 前後や $40 \mathrm{~m}$ 以深では比抵抗が増大せず，これらの 部分は難透水層とみられる。ただ,その後は深度 $40 \mathrm{~m}$ 以 浅ほほ全体で電気比抵抗が増大しているが，これは時間 を経るにしたがい孔内で鉛直方向の電解質の拡散が進ん だためであろう。BV-3 孔では深度 $17 \mathrm{~m}, 21 \mathrm{~m}, 28 \mathrm{~m}$ 付 近に地下水流動層または被圧地下水層の存在が考えられ, それらの間は難透水層が存在しているとみられる。これ ら地下水検層孔の間に位置する間隙水圧観測孔でもこの ような難透水層の存在が予想され, それによって各深度 の水圧からの換算水位が異なったものと考えられる。

赤崎地すべりでも地下水検層が実施されている（図一 11)。BV-56-7 孔では水位面以下の深度 11-20 $\mathrm{m}$ まで 一様に電導度が小さくなっており, この深度全体に地下 水の流動が認められる。BV-56-6 孔では深度約 $12 \mathrm{~m}$ まで崩積土で電導度が低下しているが, それ以深では電 導度の変化が小さいことから透水性が低くなっていると 考えられ, 地質的にも難透水性と予想される砂岩, 凝灰 岩からなる。

この結果を隣接する間隙水圧観測孔に当てはめると,
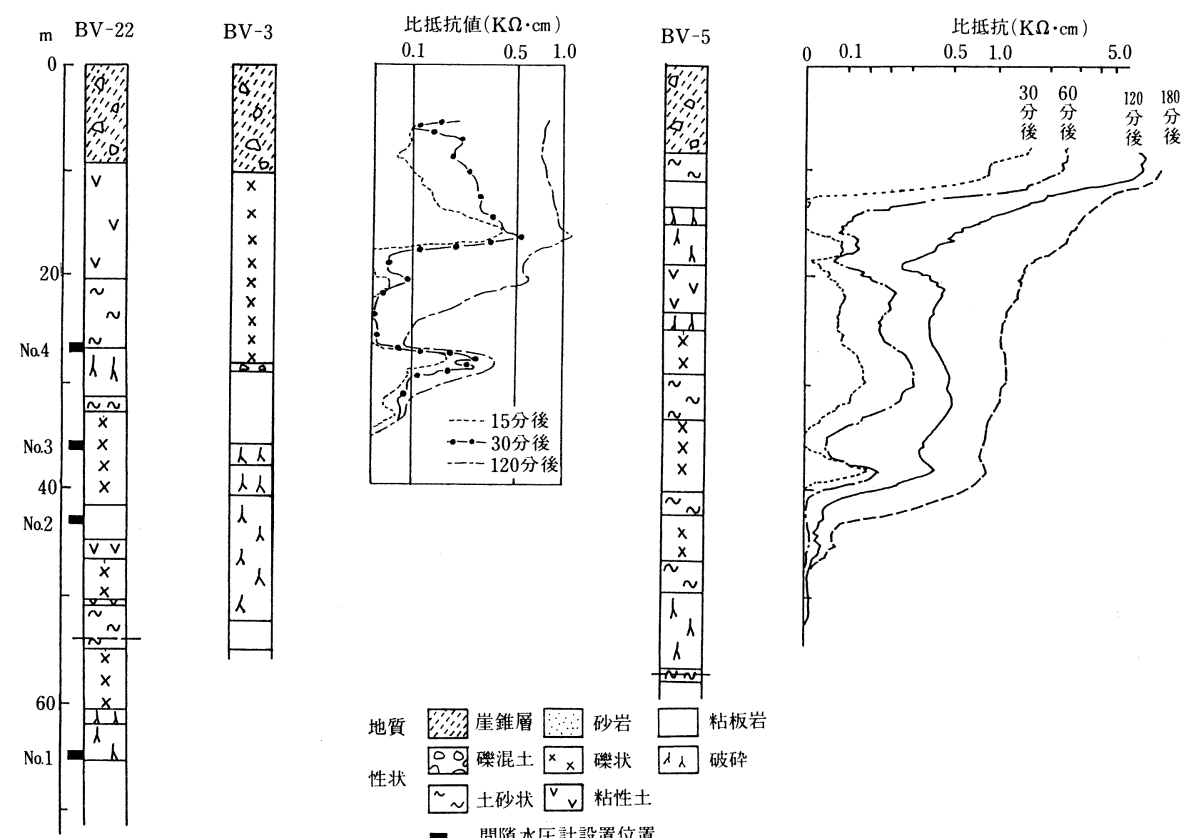

$$
\begin{aligned}
& \text { 地質 勿翟崖錐首 } \square \text { 砂岩 } \square \text { 粘板岩 }
\end{aligned}
$$

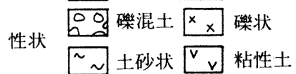

$$
\begin{aligned}
& \text { = 間隙水圧計設置位置 } \\
& \text {-・玄へり面 }
\end{aligned}
$$

図-10 口坂本地すべりの地下水検層結果及び地質柱状図（BV-3，5） (参考のため間隙水圧観測孔 $\mathrm{BV}-22$ の地質柱状図も示す) 


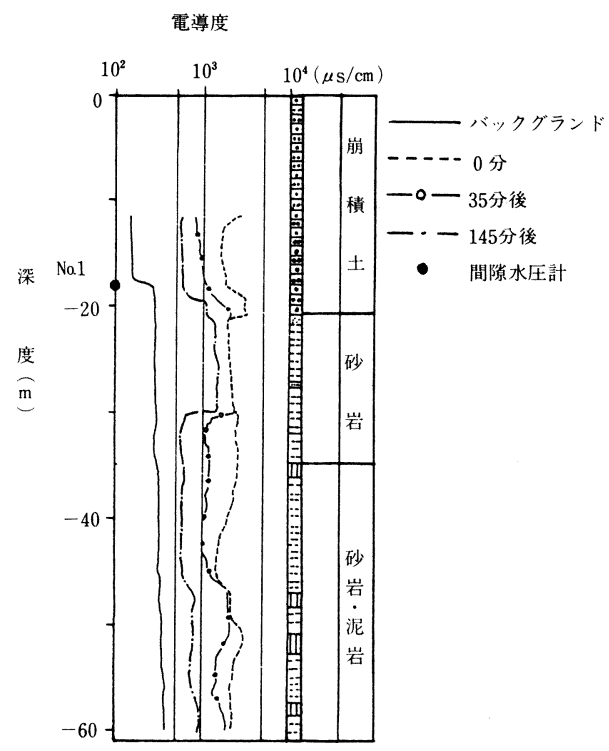

(a) BV-56-7

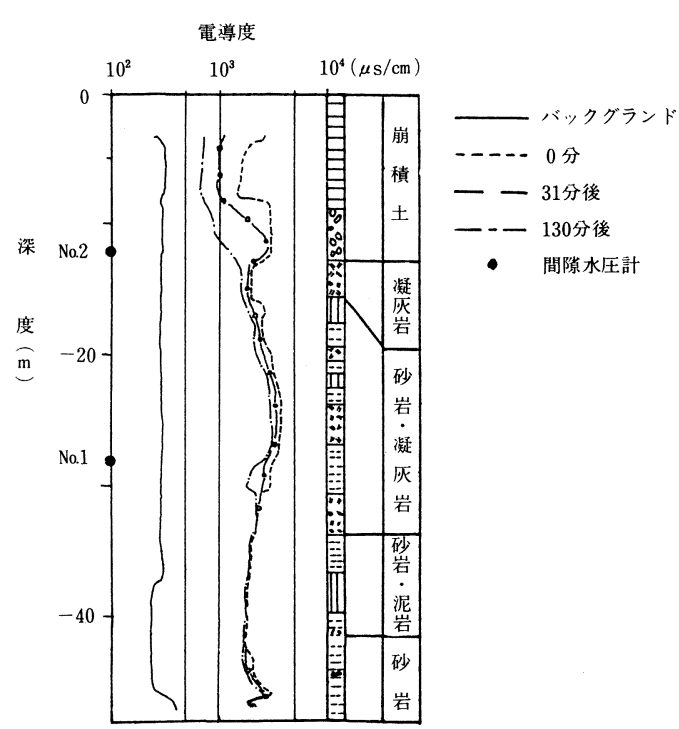

(b) BV-56-6

図ー11 赤碕地すべりの地下水検層結果
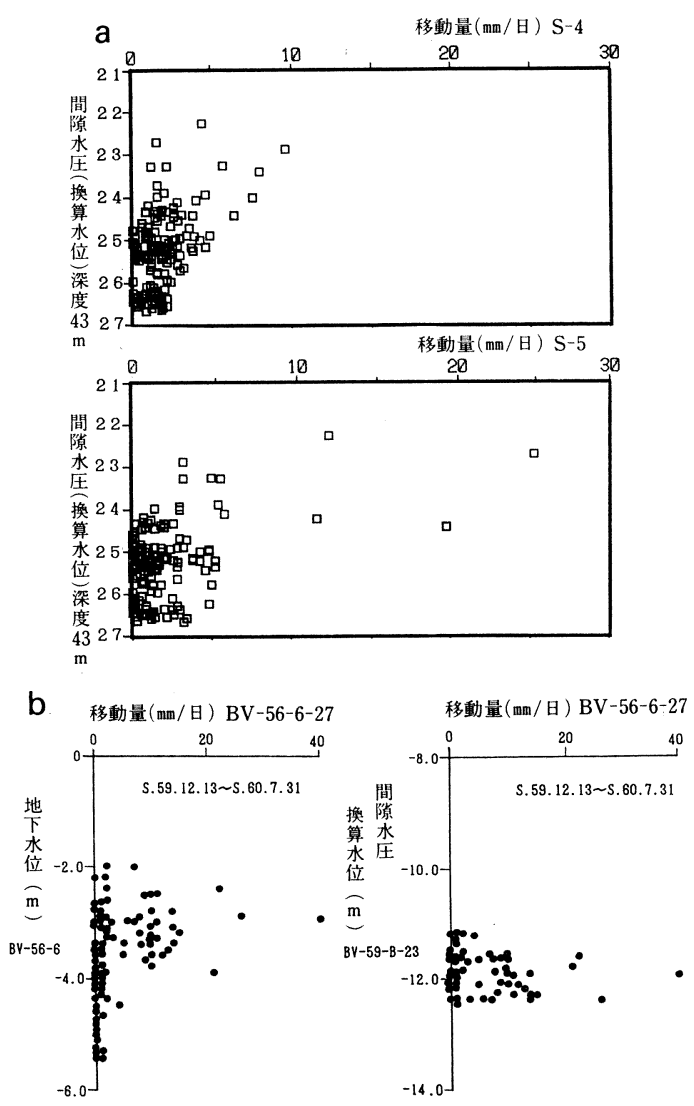

図-12 口坂本及び赤碕地すべりにおける間陌水圧（換算水 位), 地下水位と地表移動量の関係
(a) 口坂本地すべり
（b）赤碕地すべり

BV-59-A の No.1 間隙水圧計は地表面から一様に地 下水が流動している層内に位置し, BV-59-B の No. 1, No.2 間隙水圧計は透水性の低い層内に位置する。この ことが, BV-59-A と BV-59-B 孔の降雨に対する間 隙水圧変動応答の速さやパターンの違い, 及び BV59-A 孔で地下水位と水圧からの換算水位が一致する のに BV-59-B 孔の間隙水圧が静水圧分布とならない こと, の原因と考えられる。同じょうなことは猿供養寺 地すべりでも指摘されている7)。また, BV-56--6孔では 深度 $12 \mathrm{~m}$ 以深全体に難透水層とみられることから, 地 下水位は深度 $12 \mathrm{~m}$ から上の水位変動を捕らえていると みられる。

このように, 地すべり土塊中の難透水層の有無が間隙 水圧の垂直分布に影響することがわかる。

\section{6 . 地すべり移動と間吵水圧変動}

谷の内の間隙水圧観測孔に近接した孔における孔内傾 斜計によるすべり面での地すべり移動量を図ー 5 に示す。 移動量は月 1-2 回程度と観測間隔が粗いため細かな傾 向は読み取れないが, 地すべりは間隙水圧の季節的な上 昇に呼応して移動が活発化していることがわかる。

ロ坂本では地すべりブロック上部の 2 箇所の伸縮計 （図一-3 の S-4，5）で地表移動量の連続記録が得られて おりそれを図一 7 に示す。図からは間隙水圧の上昇と地 すべり移動の活発となる時期はほほ一致している。日々 の地すべり移動速度と間隙水圧の関係を図ー12(a)でみ るとその傾向が読み取れる。2 力所の伸縮計の日移動量 
の極大日はたがいに $1-3$ 日ずれることもあるが, おおま かには地すべり移動は降雨による間隙水圧上昇の結果と して生じているとみなされる。

赤崎では BV-56-6, BV-56-7 孔に設置された移 動計によって地すべり移動量を見た(図一8)。上部ブロッ クの移動量はわずかであるため, それと間隙水圧変動と の関係は議論できない。一方, BV-59-B 孔のある下部 ブロックは移動が活発である ${ }^{8)}$ 。 BV-56-6での移動量 と地下水位および隣接する BV-59-B 孔のすべり面付 近の間隙水圧との関係を見ると (図 $-12(\mathrm{~b}))$, 地すべり移 動は間隙水圧上昇期とは対応せず, むしろ移動層の浅い 部分での地下水位上昇と関係がある。

青山ほか ${ }^{2}$ や近藤・ 丸山( ${ }^{7)}$ によると新潟県の新第三紀 泥岩地すべり地では, 融雪による間隙水圧上昇が地すべ り発生の原因となるが, 地すべり斜面上の位置により間 隙水圧応答のしかたが異なる。すなわち, 頭部引張部で は融雪による間隙水圧上昇が激しいが, 圧縮部ではそれ が明瞭でないことがあり, 積雪荷重による過剰間隙水圧 の発生する場合もある。

赤崎の観測結果では, 積雪や地すべり移動発生による 土塊圧縮など過㮃間隙水圧発生の可能性のある時期には 間隙水圧上昇は対応していない。また，すべり面付近の 間隙水圧観測点の高度はブロック末端の阿賀野川より約 $20 \mathrm{~m}$ 高く, 河川水位変動が間隙水圧変動の原因とは考え にくい。 赤崎も多雪地帯の新第三紀層地すべりであり, 地下水位上昇が融雪, 降雨期と対応しているので, 地す べりは融雪，降雨による地下水供給が原因と考えられる。 今回間隙水圧が難透水層中で観測されたため変動が緩慢 で, それと地すべり移動との関係は見られなかったが, 下部ブロックの頭部引張部（主働部）では地すべり発生 の原因となる間隙水圧の上昇が生じているのではなかろ うか。

\section{7.まとめ}

高知県谷の内, 静岡県口坂本, 新潟県赤崎の各地すべ り地で地塊中の間隙水圧測定を行った。その結果, 谷の 内, 口坂本地すべり地では地下のどの深度でも降雨にか なり速く反応する間隙水圧の上昇がみられ, それが地す べり移動の活発化する時期と一致していることから, 降 雨による間隙水圧上昇が地すべり発生の原因となってい ることが実際にわかった。

しかし赤崎地すべり地ではその下部ブロックにおける すべり面の間隙水圧変化はきわめて緩慢で, 地すべり移 動時期とは対応しない。これは観測位置が適当でなく,
地すべり不安定化の原因となる間隙水圧上昇が捉えられ なかったためと思われる。地すべりの発生機構の把握や モニタリングのためには，地すべりの主働域で間隙水圧 を測定する必要があろう。

一方, 各深度の間隙水圧からの換算水位は一致せず, 従来の方法による地下水位観測值とも異なり, 地すべり 地の地下水は静水圧分布していない場合の多いことがわ かった。しかし, 中には地下水位と一致する場合もある。 これらの原因として, 地下水検層やボーリング掘削中の 孔内水位調査から難透水層の有無が関係していることが わかった。すなわち, 地表から水圧観測深度まで一様に 透水性の良い場合には, 地下水は静水圧分布に近くなり 地下水位観測值と一致するが，難透水層が挟まれると静 水圧分布にならなくなる。谷の内，口坂本地区では，深 度ごとに水圧換算水位が異なり深度が大きい程換算水位 が低くなるのに，どの深度でもおなじような水圧変動パ ターンをしめす。このことから, 地下水は難透水層には さまれたいくつかの帯水層や流動層として存在し, 降水 による間隙水圧上昇はこの層に沿って斜面方向に伝わる ものと考えられる。複層の地下水分布構造下で, 観測さ れたような間隙水圧の垂直分布, 変動パターンが生じる かを浸透流解析を用いて検討中であり，これについては 別稿で論じることとしたい。

地すべり斜面の安定計算, 対策工計画にはすべり面の 間隙水圧を把握することが必要である。このためには, 地下水検層, ボーリング掘進中孔内水位変化などの水文 地質構造の調査を実施し, 難透水層の存在する場合には 全孔ストレーナ方式の地下水位観測ではなく, すべり面 で間隙水圧を測定する必要があろう。

\section{参考文献}

1) 小川正二・池田俊雄・亀井健史・和田正 - 平松俊英: 濁沢 地すべりにおける融雪水・間隙水圧・地下水位・地温の 変動特性, 地すべり, Vol.25, No.2, pp.21〜27, 1988

2 ) 青山清道・中俣三郎・小川正二: 新潟県における地すべり と雪の相関性に関する検討, 地すべり, Vol.21, No.3, pp.11 16, 1984

3 ) 是沢一樹 - 近藤政司 - 丸山清輝 - 佐藤克徳: 猿供養寺地す ベり調查報告書(2), 土木研究所資料第 2614 号, p.83, 1988

4 ）中村浩之・綱木亮介・吉田克美: 静岡県口坂本地すべり災 害調查報告書, 土木研究所資料 2857 号, p.43, 1990

5 ）静岡県静岡土木事務所: 平成元年度口坂本地すべり調查 報告書, p.45, 1990

6 ) 申潤植: 地すべり工学一理論と実践, p.1002, 山海堂, 1989

7 ) 丸山清輝・近藤政司: 新潟県における積雪期の地すべり について, 地すべり, Vol.25, No.2, pp.18～26, 1988

8 ）吉松弘行・近藤政司・白石一夫・丸山清輝: 赤崎地すべり 調查報告書, 土木研究所資料第 2499 号, p.54, 1987 (原稿受理日 平成 3 年 10 月 9 日) 